\title{
Pathogenicity and oxidative stress in Nile tilapia caused by Aphanomyces laevis and Phoma herbarum isolated from farmed fish
}

\author{
Esam H. Ali ${ }^{1, *}$, Mohamed Hashem ${ }^{1}$, M. Bassam Al-Salahy ${ }^{2}$ \\ ${ }^{1}$ Botany Department, and ${ }^{2}$ Zoology Department, Faculty of Science, Assiut University, Assiut, Egypt
}

\begin{abstract}
Identified $(\mathrm{n}=17)$ and unidentified $(\mathrm{n}=1)$ fish-pathogenic fungal species from $10 \mathrm{gen}$ era of Oomycetes and soil fungi were isolated from 40 infected freshwater fish samples of the species Oreochromis niloticus niloticus (Nile tilapia) and Clarias gariepinus (African catfish). Samples were collected from various fish farms in the Nile Delta, Egypt. Nile tilapia were tested in aquaria for their susceptibility to the commonest Oomycetes species, Aphanomyces laevis and Achlya klebsiana, and also against the 2 most prevalent pathogenic soil fungi, Paecilomyces lilacinus and Phoma herbarum. Two techniques were used: water bath exposure and intramuscular (subcutaneous) injection. Water bath exposure to the 2 species of Oomycetes caused greater mortalities of $O$. niloticus niloticus than intramuscular injection, but the reverse was true of the soil fungal species. Regardless of the infection method, the 2 Oomycetes species were more potent pathogens than the soil fungal species. In both gills and mytomal muscles of fish infected by A. laevis and P. herbarum, we measured and compared with controls the oxidative stress parameters total peroxide (TP), lipid peroxidation (LPO) and nitric oxide (NO), as well as levels of the antioxidants vitamin $\mathrm{E}$ and glutathione (GSH), and superoxide dismutase (SOD) and catalase (CAT) activities. Infection by these 2 fungal species through either spore suspension or spore injection significantly increased oxidative damage in gills and induced marked decrease in most studied antioxidants. In addition, both routes showed similar effects and A. laevis depressed the antioxidants CAT, vitamin E and GSH more than P. herbarum.
\end{abstract}

KEY WORDS: Fungal disease - Pathogenic fungi - Pathogenicity · Nile tilapia - Antioxidants · Oxidative stress

Resale or republication not permitted without written consent of the publisher

\section{INTRODUCTION}

Fish serve as an important source of human dietary protein worldwide. Since natural stocks are increasingly overexploited, aquaculture has become an important means of meeting this demand (Fletcher et al. 1999). Intensive aquaculture conditions can promote the transmission of fish diseases (including fungal diseases), causing economic losses, hence study of these diseases has become increasingly important over the past $20 \mathrm{yr}$. Zoosporic fungi are classic secondary invaders of fish epithelial surfaces, becoming increasingly infectious under conditions of poor water quality or general immunosuppression. Oomycetes of the order Saprolegniales are res- ponsible for infections of various wild and farmed fish species (Willoughby \& Pickering 1977, Bruno \& Wood 1999, Hussein \& Hatai 2002). Within the Saprolegniales, species of Achlya, Aphanomyces and Saprolegnia are major pathogens of many fish or shellfish species (Jeney \& Jeney 1995, Daugherty et al. 1998). They are endemic to all freshwater and brackishwater habitats throughout the world (Dieguez-Uribeondo et al. 1996, Yanong 2003). Aphanomyces astaci is destructive of crayfish populations in natural environments and is mentioned in the list of 100 most unwanted alien invaders in the world, of which only 8 are microbial (McGrath \& Farlow 2005).

The most common soil fungi such as penicillia and aspergilli are likely to be present in high numbers as 
water inhabitants in sediments and biofilms whereas fusaria may be less common, since they are associated with plants (Gonçalves et al. 2006). These fungal species are mostly associated with mycotoxin production (Göttlich et al. 2002). Specific soil fungi such as some species of Aspergillus, Fusarium, Paecilomyces, Rhizomucor and Phoma have been implicated in fish diseases (Olufemi et al. 1983, Hatai et al. 1986, Lightner et al. 1988, Crow et al. 1995, Wolf \& Smith 1999). Most of these species are known to cause systemic disease in fish (Ellis et al. 1983).

Fungal diseases of fish are characterized by visible white to grey patches of filamentous mycelium on the body or fins of freshwater fish (Van West 2006). The mycelium may have already penetrated into body tissues, and the fungal reproductive stage initiated (Goldstein 1983). Severe infections result in lethargic behaviour, loss of equilibrium and commonly death of the fish (Bruno \& Poppe 1996).

Aquatic organisms, especially fish, are exposed to many sources of pollutants that cause oxidative damage such as metals (Almeida et al. 2002), pesticides (Sayeed et al. 2003) and the cyanobacterial toxin microcystein (Li et al. 2003, Jos et al. 2005). Also, some species of the genus Aphanomyces induce skin and muscle lesions termed ulcerative mycosis in fish from western Atlantic estuarine waters (Dykstra \& Kane 2000). Most studies of the pathological effect of fungal infection on fish have not focused on studying the oxidant or antioxidant status. The increase in oxidative biomarkers such as total peroxide (TP), lipid peroxidation (LPO) and nitric oxide (NO) are potential indicators of tissue damage. TP as measured by xylenol orange and induced at an early stage of a long chain of reactions, ultimately forms LPO as terminal products (Lushchak et al. 2005). TP forms includes lipid peroxide (LOO·), lipid hydroperoxide (LOOH), hydrogen peroxide $\left(\mathrm{H}_{2} \mathrm{O}_{2}\right)$, nitrogen peroxide or dioxide $\left(\mathrm{NO}_{2}\right)$. The increase in malondialdehyde (MDA) concentration is used as an index of oxidative breakdown of lipids (LPO) in cell membranes and an indirect biomarker of free radical generation (Gutteridge 1995). The antioxidant levels such as glutathione (GSH), activities of catalase (CAT) and superoxide dismutase (SOD) in both gill and muscle are also affected by the fungal infection.

In Egypt, fish culturists occasionally complain about signs of fungal infection in their farms which cause severe damage to production and high mortality rates. The goals of this study were (1) to trace the fungal diseases of the most popular freshwater fish species Oreochromis niloticus niloticus (Nile tilapia aka Bolti), and Clarias gariepinus (African catfish) in Egyptian farms in Menzalah (Kafr El-Sheikh Governorate) and Abbassa (El-Sharqyia Governorate) cities, (2) to exam- ine the potency of the 2 most prevalent identified pathogenic species of Oomycetes (Achlya klebsiana and Aphanomyces laevis) and 2 soil fungi isolates (Paecilomyces lilacinus and Phoma herbarum) which may infect $O$. niloticus niloticus in aquaria, (3) to understand the mode of action of such pathogens, and (4) to investigate the effect of infection with spore suspension and spore injection of $A$. laevis and $P$. herbarum on oxidant or antioxidant parameters in gill and muscle of the Nile tilapia O. niloticus niloticus.

\section{MATERIALS AND METHODS}

Investigation of pathogenic Oomycetes and soil fungi. Collection of freshwater fish species: Forty samples of 2 freshwater fish species, Oreochromis niloticus niloticus and Clarias gariepinus (20 samples of each species), were collected from fish farms located in El-Menzalah (Kafr El-Sheikh Governorate) and Abbassa (El-Sharqyia Governorate) cities in the northern Nile Delta, Lower Egypt. Samples were collected from separate farms where 4 individuals of each species were considered as 1 sample. The collected samples showed visual signs of fungal infection (cottonymycelial growth and melanized spots). Collected samples were kept in thermostat ice tanks and brought to the laboratory for mycological analysis.

Isolation of pathogenic Oomycetes species: Fish samples were washed in running water to remove any attached debris. They were then rinsed twice in distilled water and blot dried with sterile filter paper. Small portions of the fish species with signs of fungal infection were aseptically sliced to $\sim 2 \mathrm{~mm}$ diameters. These slices were picked from the fish body and inoculated onto sterilized petri dishes containing glucose peptone and glucose yeast extract agar media ( 3 plates of each). Glucose yeast extract agar medium is used for the isolation of Aphanomyces species of the family Saprolegniaceae (Hatai \& Egusa 1979) whereas glucose peptone agar medium is frequently used for the isolation of other members of the family Saprolegniaceae (Willoughby \& Pickering 1977). Petri dishes with infected fish slices were then incubated at $22 \pm 2^{\circ} \mathrm{C}$ for $10 \mathrm{~d}$. Mycelial discs of the growing colonies were prepared from the periphery of the vegetative growth using a sterilized cork borer. They were introduced into sterilized petri dishes containing sterilized distilled water and germinating and sterilized halved sesame seeds. Incubation was at $22 \pm 2^{\circ} \mathrm{C}$ for $10 \mathrm{~d}$ during which Oomycetes species were identified based on morphological characteristics.

Isolation of pathogenic soil fungi species: Infected fish samples were washed in running water to remove sediments. The clean samples were rinsed twice in dis- 
tilled water and dried with sterilized filter papers. The infected parts of the fish samples were sliced (about $1 \mathrm{~cm}^{2}$ ). Five pieces were inoculated onto either Sabouraud's agar or potato dextrose agar (PDA) medium (Smith \& Onions 1983). Three plates (1 sample) were used for each medium. Media were supplemented with chloramphenicol and streptomycin $\left(66 \mu \mathrm{g} \mathrm{ml}^{-1}\right)$ to suppress the growth of bacteria. Plates were incubated at $28 \pm 1^{\circ} \mathrm{C}$ for 5 to $7 \mathrm{~d}$ and the growing fungal species were examined and identified.

Identification of pathogenic Oomycetes and soil fungi species: Key references employed for the identification of the isolated Oomycetes species from the infected fish species were Coker (1923), Johnson (1956), Sparrow (1960), Scott (1961) and Seymour (1970). Soil fungi species were identified on the basis of cultural, morphological macroscopic and microscopic features using identification keys of Moubasher (1993), Raper \& Fennell (1965), Pitt (1979) and Pitt \& Hocking (1997).

Pathogenicity experiments. Design of water tanks and fish preparation: The pathogenicity experiments (direct spore exposure experiment and spore injection experiment) used 10 glass tanks, each using $6 \mathrm{~mm}$ thick glass, $\sim 50 \mathrm{~cm}$ height, $50 \mathrm{~cm}$ length and $45 \mathrm{~cm}$ width. Each tank contained $25 \mathrm{l}$ of tap water and also had a fine steel-mesh cover for protection and to minimize water evaporation during the experiment. Two electrical air pumps with air stones were used as oxygen suppliers for each water tank to maintain dissolved oxygen levels of between 90 and $95 \%$ saturation. The $\mathrm{pH}$ of the water was kept between $\mathrm{pH} 7$ and $\mathrm{pH}$ 8. The temperature was maintained at $22 \pm 2{ }^{\circ} \mathrm{C}$ during the $3 \mathrm{wk}$ experimental period, with a $12 \mathrm{~h}$ light:12 h dark photoperiod.

Fish samples of Oreochromis niloticus niloticus were purchased from commercial fisheries and brought alive in Nile water free from fungal propagules (mycologically investigated) to our Laboratory of Aquatic Fungi, Botany Department, Assiut University. Fish samples were approximately of the same weight and length and they were of good health. After inoculation of water tanks or injection of fish with the desired inocula of pathogenic species (cysts for Oomycetes species and spore suspension for soil fungi), the samples were randomly distributed into 8 tanks (15 fish per tank). Two water tanks without inoculum functioned as controls. Fishes were fed daily with commercial feed at $3 \%$ of body weight. Two experiments were designed to study the pathogenicity of 4 pathogenic strains; each experiment was repeated 3 times.

Tested Oomycetes species: Two strains of Oomycetes species, Achlya klebsiana LAF26 and Aphanomyces laevis LAF30, were used for the 2 routes of pathogenicity tests. The 2 species of Oomycetes were isolated from diseased fish samples and were deposited in the Herbarium of our Laboratory of Aquatic Fungi. To obtain cysts of the 2 Oomycetes species, A. klebsiana was cultured on glucose peptone solid medium (Willoughby \& Pickering 1977) whereas A. laevis was grown on glucose yeast extract agar medium (Hatai \& Egusa 1979) at $20 \pm 2{ }^{\circ} \mathrm{C}$ for $5 \mathrm{~d}$. Agar pieces $(1 \mathrm{~cm})$ were taken from the colony margins and were aseptically introduced into $12 \mathrm{~cm}$ diameter petri dishes containing sterilized distilled water and sterilized germinating halves of sesame seeds as a capture material. Plates were then incubated at $22 \pm 2^{\circ} \mathrm{C}$ for $7 \mathrm{~d}$ where zoosporangial discharge and zoospore encystment were best attained. A haemocytometer was used for counting cysts of Oomycetes species and spore numbers of soil fungi. Two $\mathrm{ml}$ of zoospore suspension contained $\sim 3 \times 10^{6}$ cysts of A. klebsiana or $\sim 1 \times 10^{5}$ cysts of A. laevis.

Tested soil fungi species and preparation of the inoculum: Inocula of Phoma herbarum and Paecilomyces lilacinus were prepared from $5 \mathrm{~d}$ old cultures on PDA medium. A concentrated spore suspension was made by shaking discs of the cultural medium containing spores and hyphae in sterilized tap water to develop about $10^{6}$ colony forming units per $\mathrm{ml}$ (cfu $\mathrm{ml}^{-1}$ ). A desired volume from the prepared inocula was added to the fish culture to achieve the concentration of $10^{3} \mathrm{cfu} \mathrm{ml} \mathbf{m}^{-1}$.

Pathogenicity techniques. Direct exposure (bath exposure) of $O$. niloticus niloticus in water tanks to fungal spores: Of each tested Oomycetes species, $50 \mathrm{ml}$ of cyst suspension (equivalent to about $25 \times 3 \times$ $10^{6}$ cysts of Achlya klebsiana or $25 \times 1 \times 10^{5}$ cysts of Aphanomycas laevis) was introduced into individual water tanks and used as bath exposure. For the tested soil fungi species, $100 \mathrm{ml}$ of spore suspension was added to each individual water tank (1 fungal species per tank). All inocula were added to the water tanks just $1 \mathrm{~d}$ before fish exposure. Each water tank received 15 healthy Oreochromis niloticus niloticus. Control water tanks with the same number of fish and without spore inoculation were also prepared. Visual observations of the fungal growth (cottony mycelial growth, melanized grey or brown lesions) on each individual fish were followed after $1 \mathrm{~d}$ of exposure and extended for $3 \mathrm{wk}$ (the period of experiment). Fish mortalities, moribund and survived fishes were recorded during the period of the experiment. Dead fish were removed from the water tanks and preserved in a refrigerator in sterile containers for estimation of the antioxidant and oxidative stress parameters in their gills and muscles. Also, at the end of the experiment control fish were collected for the same purpose.

Intramuscular (subcutaneous) spore injection experiment: Four groups of 15 fish were injected subcu- 
taneously (intramuscularly) with $1 \mathrm{ml}$ per fish of 1 of the 4 fungal inocula (1 fungal species per group) using a sterile syringe following scale abrasion $(\sim 1 \mathrm{~cm}$ diameter). Each treatment group was kept in a separate water tank, under the same light, temperature, and water chemistry conditions as for the bath exposure experiment. Additional water tanks containing uninjected fish were used as controls. The experiment was followed for $3 \mathrm{wk}$ and dead fish were removed immediately from water tanks. The dead, moribund and surviving fish were counted at the end of the experiment.

Fish diagnosis: The diagnosis of fungal infection was based on the appearance of cottony mycelial growth or melanization (grey or brown lesions) on the surface of the fish. The numbers of fish mortalities, moribund and surviving fishes were recorded for each pathogenicity technique of the tested fungal species. The dead fish and controls were also collected and subjected to antioxidant and oxidative stress analysis.

Oxidative stress and antioxidant assays. Preparation of fish samples: At the end of the experiments, pieces of gills (right) and muscles (from lateral myotomal musculature of mixed muscles; red and white) were excised from the dead fish and the normal unexposed samples. Homogenates $(10 \% \mathrm{w} / \mathrm{v})$ were made in phosphate buffer ( $\mathrm{pH}$ 7.4) using a homogenizer (model IKA-WERKE, $\mathrm{D}_{1}$ 18 BASIC). Homogenates were then centrifuged at $13000 \times g$ for $15 \mathrm{~min}$ to separate the cytosol. All the samples were deep frozen at $-20^{\circ} \mathrm{C}$ pending analysis.

Oxidative stress assays: TP and LPO were measured according to the methods of Harma et al. (2005) and Ohkawa et al. (1979), respectively. NO was assayed by Griess reagent according to the method of Ding et al. (1988).

Antioxidant assays: GSH was determined as described by Ellman (1959) and Ravi et al. (2004). SOD and CAT activities were measured by the methods of Misra \& Fridovich (1972) and Beers \& Sizer (1952), respectively. Vitamin E was determined by the method of Roe (1961). Total protein was measured as described by Lowry et al. (1951).

Statistical analysis: The oxidative stress and antioxidant assay data were expressed as mean \pm standard error of the mean (SEM). The results were analyzed statistically using column statistics and 1-way ANOVA with
Newman-Keuls multiple comparison test as a posttest. These analyses were carried out using the computer statistics Prism 3.0 Package (Graph and Software). The minimum level of significance was set at $\mathrm{p}<0.05$.

\section{RESULTS AND DISCUSSION}

The results presented in Table 1 indicate that 17 identified and 1 unidentified species belonging to 10 genera of Oomycetes and soil fungi were isolated from the 40 collected infected fish samples of Oreochromis niloticus niloticus (Figs. 1 \& 2) and Clarias gariepinus (Fig. 3). Of these 10 identified genera, 6 genera were soil fungi. The remaining 4 Oomycetes genera comprised 7 identified and 1 unidentified species.

\section{Oomycetes}

Achlya klebsiana was the most prevalent species of Oomycetes, but was isolated only from Oreochromis niloticus niloticus (9 out of 20 samples). The species Aphanomyces laevis was less prevalent than A. klebsiana in $O$. niloticus niloticus, but occurred in both

Table 1. Number of cases out of 20 pooled samples (each sample $=4$ fish) and frequency of fish-pathogenic species of Oomycetes and soil fungi isolated from Oreochromis niloticus niloticus and Clarias gariepinus obtained from fish farms in the Nile Delta, Egypt. $\mathrm{H}=$ high frequency, isolated from $>10$ samples; $\mathrm{M}=$ moderate frequency, isolated from 6 to 10 samples; $\mathrm{L}=$ low frequency, isolated from 3 to 5 samples; $\mathrm{R}=$ rare frequency, isolated from $<3$ samples

\begin{tabular}{|c|c|c|c|c|}
\hline \multirow[t]{2}{*}{ Isolated species } & \multicolumn{2}{|c|}{ O. n. niloticus } & \multicolumn{2}{|c|}{ C. gariepinus } \\
\hline & $\begin{array}{l}\text { No. of } \\
\text { cases }\end{array}$ & Frequency & $\begin{array}{l}\text { No. of } \\
\text { cases }\end{array}$ & Frequency \\
\hline \multicolumn{5}{|l|}{ Oomycetes } \\
\hline Achlya klebsiana & 9 & M & - & - \\
\hline A. proliferoides & 1 & $\mathrm{R}$ & 4 & $\mathrm{~L}$ \\
\hline Aphanomyces laevis & 6 & M & 7 & M \\
\hline Dictyuchus monosporus & 3 & $\mathrm{~L}$ & 1 & $\mathrm{R}$ \\
\hline D. sterilis & 1 & $\mathrm{R}$ & 5 & $\mathrm{~L}$ \\
\hline Saprolegnia diclina & 2 & $\mathrm{R}$ & - & - \\
\hline S. ferax & 2 & $\mathrm{R}$ & 3 & $\mathrm{~L}$ \\
\hline Saprolegnia spp. & 4 & $\mathrm{~L}$ & 6 & $\mathrm{M}$ \\
\hline \multicolumn{5}{|l|}{ Soil fungi } \\
\hline Aspergillus flavus & 12 & $\mathrm{H}$ & 6 & $\mathrm{M}$ \\
\hline A. niger & 10 & M & 8 & M \\
\hline A. parasiticus & 7 & M & 4 & $\mathrm{~L}$ \\
\hline A. versicolor & - & - & 5 & $\mathrm{~L}$ \\
\hline Mucor heamalis & 3 & $\mathrm{~L}$ & - & - \\
\hline Paecilomyces lilacinus & 9 & M & 8 & M \\
\hline P. variotii & 7 & M & 7 & M \\
\hline Phoma herbarum & 7 & M & 4 & $\mathrm{~L}$ \\
\hline Rhizopus stolonifer & 3 & $\mathrm{~L}$ & 3 & $\mathrm{~L}$ \\
\hline Trichoderma hamatum & 5 & $\mathrm{~L}$ & 4 & $\mathrm{~L}$ \\
\hline
\end{tabular}




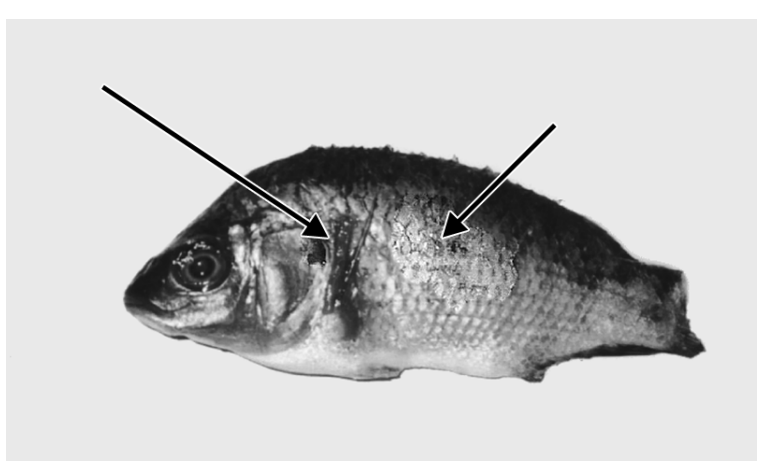

Fig. 1. Oreochromis niloticus niloticus. Nile tilapia (aka Bolti) with melanized grey to black lesions (arrows) of fungal infection on the body surface

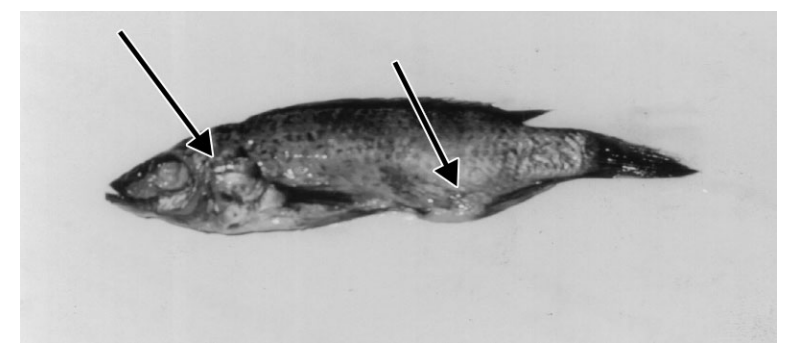

Fig. 2. Oreochromis niloticus niloticus. Nile tilapia infected with Oomycetes species as denoted by cottony growth (arrows) on the body surface

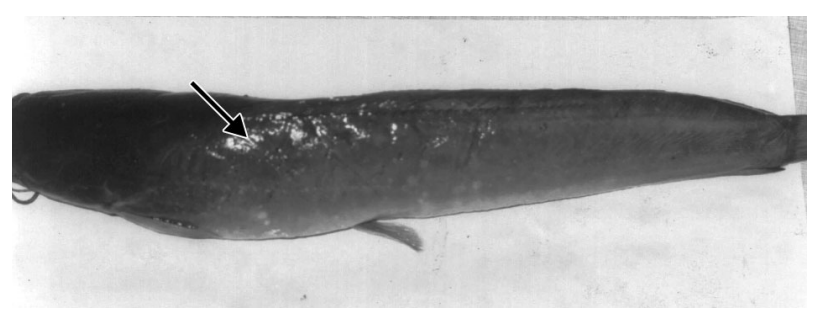

Fig. 3. Clarias gariepinus. African catfish showing infected body patches of cottony appearance (arrow) of pathogenic Oomycetes

investigated fish species (isolated from 7 and 6 out of 20 samples each of Clarias gariepinus and O. niloticus niloticus, respectively).

Achlya proliferoides was rarely encountered (only 1 fish sample) from Oreochromis niloticus niloticus whereas it was observed at low frequency (4 out of 20 fish samples) from Clarias gariepinus. Dictyuchus species indicated in Table 1 were also either isolated at low or rare frequency from the 2 investigated fish species. Both Saprolegnia diclina and Saprolegnia ferax were isolated at rare frequency (only 2 samples each) from O. niloticus niloticus. Conversely, S. ferax was recorded at low frequency from C. gariepinus and $S$. diclina was not isolated in this species. The unidentified Saprolegnia species were isolated at moderate frequency from C. gariepinus (6 samples) while they were found at low frequency from $O$. niloticus niloticus (only in 4 samples).

This study is the first report dealing with fish problems in aquaculture in the Nile Delta of Egypt. A diverse range of Oomycetes species was isolated during this study, each of which has the ability to infect fish species. Based on the number of fish samples collected and also the number of Oomycetes isolates, the data may indicate that Oreochromis niloticus niloticus is more susceptible to Oomycetes infection (8 species) than Clarias gariepinus (6 species). Achlya klebsiana and Aphanomyces laevis were the commonest pathogenic Oomycetes species (moderately encountered) although A. klebsiana was isolated only from O. niloticus niloticus. Most of the other pathogenic species of Oomycetes (with the exception of Saprolegnia diclina) were isolated from both $O$. niloticus niloticus and C. gariepinus. Similarly, Krishna et al. (1990) recorded mycosis due to Saprolegnia parasitica in Indian major carps; skin, gill and fin had cotton-like greyish white to light brown deposits along with areas of necrosis. In addition, Ogbonna \& Alabi (1991) surveyed the species of zoosporic fungi associated with mycotic infections of fish in a Nigerian freshwater fish pond. They isolated 24 zoosporic fungi species from the infected fishes, and reported that Achlya racemosa, Aphanomyces laevis, Dictyuchus sterilis, Saprolegnia ferax, S. litoralis and $S$. parasitica had $100 \%$ prevalence among the infected fish. There were similarities in fungal species isolated from the infected individuals in the fish pond and those isolated from the hatchery; Clarias lazera and Tilapia zilli had the highest number of fungal isolates (Ogbonna \& Alabi 1991). Furthermore, Khulbe et al. (1995) isolated 8 species of zoosporic fungi (Achlya debaryana, A. flagellata, A. klebsiana, A. laevis, Saprolegnia diclina, S. ferax, S. parasitica and Pythium sp.) from the fish species Mastacembelus armatus, Mystus vitatus, Nadus nadus, Tor putitora, and Tor tor from a single reservoir in India. Mondal \& De (2002) recorded Aphanomyces laevis as a new virulent parasite of Aplocheilus panchax, causing cotton-wool disease involving the skin and fins. Moreover, Johnson et al. (2004) found that along the eastern seaboard of the USA, Atlantic menhaden Brevoortia tyrannus developed characteristic ulcerative lesions, a condition termed ulcerative mycosis. These lesions are identical to those observed across Asia in fish affected by epizootic ulcerative syndrome, a condition caused by the Oomycete Aphanomyces invadans. A. flagellata and S. parasitica appeared to be the most virulent of the species isolated by Johnson et al. (2004). 


\section{Soil fungi}

Ten identified species of soil fungi were isolated from the 2 tested fish species (Table 1). Aspergillus was represented by 4 pathogenic species. Of these, $A$. flavus was highly prevalent (12 out of 20 fish samples) in Oreochromis niloticus niloticus but it was only moderately prevalent in Clarias gariepinus (6 samples). A. niger was recorded at moderate frequency in both fish species (10 and 8 samples, respectively). A. parasiticus was encountered at moderate frequency (7 samples) from $O$. niloticus niloticus and at low frequency (4 samples) from C. gariepinus. However, $A$. versicolor was isolated at low frequency (5 samples) from C. gariepinus only. Similarly, Mucor heamalis was isolated at low frequency (3 samples) only from $O$. niloticus niloticus.

Both Paecilomyces lilacinus and Paecilomyces variotii were encountered (at similar moderate frequencies) in both infected fish species. Phoma herbarum was isolated at moderate frequency from Oreochromis niloticus niloticus and at low frequency from Clarias gariepinus ( 7 and 4 fish samples, respectively). Rhizopus stolonifer and Trichoderma hamatum were isolated at low frequency from both tested fish species (3 to 5 samples each).

Fish contamination with these fungi either as saprophytes or parasites has been previously reported. Fungal species from the genera Aspergillus, Fusarium, Paecilomyces, Rhizomucor and Phoma have been implicated in fish diseases by multiple authors (Olufemi et al. 1983, Hatai et al. 1986, Lightner et al. 1988, Crow et al. 1995, Wolf \& Smith 1999).

\section{Pathogenicity of Oomycetes and soil fungi on O. niloticus niloticus in aquaria}

Results in Table 2 indicate that direct bath exposure of Oreochromis niloticus niloticus to the inoculum of the 2 tested Oomycetes species caused more fish mortalities than subcutaneous injection. This may be attributed to the immediate effect of bath exposure on all fish organs, whereas the effect of subcutaneous inocculation is limited by the time required for the injected spores/cysts to develop and proliferate throughout the fish tissues. However, Aphanomyces laevis caused more mortalities in $O$. niloticus niloticus than Achlya klebsiana regardless of the exposure method. Most O. niloticus niloticus mortalities occurred during the first week of exposure. The mortality rate decreased by the second week of inoculation and was the lowest by the third week.

However, intramuscular injection resulted in low mortalities of Oreochromis niloticus niloticus in the first week and the mortalities increased in the subsequent $2 \mathrm{wk}$ of the experiment. In comparison, great variations were obtained when $O$. niloticus niloticus were inoculated with Phoma herbarum and Paecilomyces lilacinus (Table 2). Intramuscular injection with the spores of these fungi resulted in more fish mortalities than bath exposure and most mortalities occurred in the second week after inoculation but fewer mortalities were recorded in the third week. Mortalities from direct/bath exposure were higher in the third week than in the first and second weeks (Table 2). Our data also indicated that $P$. herbarum was a more potent pathogen to the Nile tilapia than $P$. lilacinus since it caused more mortalities whatever the inoculation methodology.

Our results agree with Khulbe (1989), who tested the infection ability of 4 species of the Saprolegniales (Brevilegnia subclavata, Geolegnia inflata, Protoachlya oryzae and Scoliolegnia centrica) by artificial inoculation experiments. All except G. inflata infected the test fish (Carassius auratus, Puntius conchonius, Puntius ticto and Nemacheilus rupicola). In addition, 80 isolates of various Oomycetes species belonging to Achlya, Aphanomyces, Dictyuchus, Protoachlya, Saprolegnia, Thraustotheca and Pythium were observed to infect temperate fish of Kumaun Himalaya, India

Table 2. Oreochromis niloticus niloticus. Mortalities per week, total mortalities (T) and surviving fishes (SF) out of 15 individuals after 3 wk (W1, W2, W3) of spore exposure or intramuscular injection by inocula of 2 Oomycetes species and 2 species of soil fungi in water tanks

\begin{tabular}{|c|c|c|c|c|c|c|c|c|c|c|c|c|}
\hline \multirow[t]{3}{*}{ Fungal species } & \multirow{3}{*}{$\overline{\mathrm{W} 1}$} & \multirow{2}{*}{\multicolumn{3}{|c|}{$\begin{array}{l}\text { - Bath exposure } \\
\text { Mortality }\end{array}$}} & \multirow{3}{*}{$\mathrm{SF}$} & \multicolumn{5}{|c|}{ - Intramuscular injection -} & \multirow{3}{*}{$\begin{array}{l}\text { Control } \\
\text { Mortality }\end{array}$} & \multirow{3}{*}{ SF } \\
\hline & & & & & & & Mor & & & $\mathrm{SF}$ & & \\
\hline & & W2 & W3 & $\mathrm{T}$ & & W1 & W2 & W3 & $\mathrm{T}$ & & & \\
\hline \multicolumn{13}{|l|}{ Oomycetes } \\
\hline Achlya klebsiana & 5 & 3 & 3 & 11 & 4 & 2 & 4 & 4 & 10 & 5 & - & 15 \\
\hline Aphanomyces laevis & 8 & 5 & 1 & 14 & 1 & 2 & 6 & 4 & 12 & 3 & - & 15 \\
\hline \multicolumn{13}{|l|}{ Soil fungi } \\
\hline Phoma herbarum & 2 & 2 & 3 & 7 & 8 & 2 & 4 & 3 & 9 & 6 & - & 15 \\
\hline Paecilomyces lilacinus & 1 & 1 & 2 & 4 & 11 & 1 & 4 & 2 & 7 & 8 & - & 15 \\
\hline
\end{tabular}


(Sati 1981). The parasitic ability of each isolate was confirmed by artificial inoculation experiments under laboratory conditions; however, Sati (1981) found that the species of Saprolegnia and Achlya were more virulent fish parasites than those of Aphanomyces, Dictyuchus, Protoachlya, Pythium and Thraustotheca. Furthermore, Khulbe et al. (1995) found that experimental inoculation with 8 associated zoosporic fungal species on adult fish Puntius conchonius in the laboratory produced clinical signs similar to those observed on infected wild fish. Stueland et al. (2005) examined 7 Saprolegnia spp. strains for their pathogenicity to Atlantic salmon Salmo salar. Two of the Saprolegnia strains tested caused $89 \%$ and $31 \%$ cumulative mortality in challenged salmonids and were significantly more pathogenic than other tested strains. The positive control (Saprolegnia parasitica) caused 18\% mortality, but this was not significantly higher than non-pathogenic strains ( 0 to $3 \%$ cumulative mortality).

Carballo et al. (1995) reported that bath exposure to saprolegniosis agents induced no or relatively low mortality for rainbow trout Oncorhynchus mykiss. In addition, Singhal et al. (1987) found significant mortalities following intramuscular injection.

The visual examination of fish indicated that the infection was localized as minimal or extensive lesions at the site of injection when healthy fish were subjected to cutaneous injection. Spore injection caused more mortalities in fish than the bath exposure in Phoma herbarum and Paecilomyces lilacinus. The spread of Oomycetes hyphae was pronounced throughout the whole body of fish when the fish were exposed to inoculation in water.

Kiryu et al. (2003) reported that Atlantic menhaden Brevoortia tyrannus developed characteristic skin ulcers in response to infection by the Oomycete Aphanomyces invadans. In their pathogenicity investiga- tion, they found that survival rates declined with increasing zoospore dose; moribund and dead fish exhibited characteristic ulcerous lesions at the injection site starting at $13 \mathrm{~d}$ post-injection.

\section{Oxidative stress biomarkers}

The potential indicators of tissue damage LPO and TP were markedly increased in the gills of fish exposed to both routes of infection with Aphanomyces laevis and Phoma herbarum (Table 3, Fig. 4a,b). There was a significant rise of LPO and TP in the gills of $P$. herbarum-infected fish (cutaneous injection) compared with the control; this increase was higher than those recorded in A. laevis-infected fish. In contrast, the infections showed a weak effect in muscle (Fig. 4a,b). The NO level in muscle and gill was mostly normal after exposure to P. herbarum (Table 3, Fig. 4c), but it was increased significantly in the muscle of fish exposed to spores of $A$. laevis.

In this regard, oxidative stress biomarkers are becoming increasingly important in the field of ecotoxicology (Pandey et al. 2003). Jos et al. (2005) revealed that microcystein induces oxidative stress in fish liver and kidneys after 14 and $21 \mathrm{~d}$ of treatment. Also, administration of Bacillus calmette into mice significantly increased liver LPO (Wang et al. 2005). Gills are the main contributor of reactive oxygen species (ROS) generation in fish (Wilhelm Filho et al. 2002). In addition, in fish exposed to cyanobacterial cells, LPO increased in all studied organs especially liver (3- to 4-fold) (Prieto et al. 2007).

Sosa et al. (2007) indicated that Aphanomyces induced skin ulcers with deeply penetrating hyphae in the surrounding muscle tissue in diseased fish (mullet Mugil curema). Most studies focused on the ability of

Table 3. Oreochromis niloticus niloticus. Effect of exposure to Aphanomyces laevis and Phoma herbarum by spore suspension (SS) or spore injection (SI) on oxidative stress markers lipid peroxidation (LPO, nmol mg ${ }^{-1}$ protein), nitric oxide ( $\mathrm{NO}, \mathrm{nmol} \mathrm{mg}^{-1} \mathrm{protein}$ and total peroxide (TP, nmol mg ${ }^{-1}$ protein) and antioxidants vitamin $\mathrm{E}\left(\mu \mathrm{g} \mathrm{mg}{ }^{-1}\right.$ protein), glutathione (GSH, $\mu \mathrm{g} \mathrm{mg} \mathrm{mg}^{-1}$ protein), activities of catalase (CAT, $\mathrm{U} \mathrm{min}^{-1} \mathrm{mg}^{-1}$ protein) and superoxide dismutase (SOD, $\mathrm{U} \mathrm{min} \mathrm{mg}^{-1} \mathrm{mg}^{-1}$ protein) in gills (G) and muscles (M) of Nile tilapia.

Data are mean \pm SEM. * Significantly different from control $(\mathrm{p}<0.05)$

\begin{tabular}{|c|c|c|c|c|c|c|c|c|c|}
\hline \multirow{2}{*}{ Treatment } & \multirow{2}{*}{ Tissue } & \multirow{2}{*}{ Route } & \multicolumn{3}{|c|}{ —xidative stress markers } & \multirow[b]{2}{*}{ Vit E } & \multirow{2}{*}{$\begin{array}{l}\text { Antioxidants } \\
\text { SOD }\end{array}$} & \multicolumn{2}{|c|}{ ts } \\
\hline & & & LPO & NO & TP & & & GSH & CAT \\
\hline Control & G & & $3.42 \pm 0.13$ & $6.24 \pm 0.65$ & $52.41 \pm 12.38$ & $0.44 \pm 0.06$ & $2.07 \pm 0.21$ & $0.58 \pm 0.06$ & $5.53 \pm 0.63$ \\
\hline \multirow[t]{3}{*}{ A. laevis } & G & SS & $2.29 \pm 0.43$ & $5.87 \pm 0.77$ & $137.77 \pm 13.98^{*}$ & $0.26 \pm 0.03^{*}$ & $4.24 \pm 0.38^{*}$ & $0.19 \pm 0.02^{*}$ & $0.86 \pm 0.12^{*}$ \\
\hline & & SI & $7.78 \pm 0.81^{*}$ & $4.27 \pm 0.44^{*}$ & $31.34 \pm 117.12^{*}$ & $0.26 \pm 0.03^{*}$ & $4.03 \pm 0.44^{*}$ & $0.22 \pm 0.04^{*}$ & $0.94 \pm 0.17^{*}$ \\
\hline & M & SS & $2.58 \pm 0.66$ & $6.09 \pm 0.31^{*}$ & $113.87 \pm 12.21^{*}$ & $0.35 \pm 0.04$ & $3.42 \pm 0.37$ & $0.16 \pm 0.03^{*}$ & $1.06 \pm 0.12^{*}$ \\
\hline \multirow{3}{*}{ P. herbarum } & & SI & $9.30 \pm 1.59^{*}$ & $7.43 \pm 0.45$ & $194.71 \pm 15.69^{*}$ & $0.42 \pm 0.03$ & $3.99 \pm 0.28^{*}$ & $0.35 \pm 0.05^{*}$ & $1.60 \pm 0.26^{*}$ \\
\hline & $\mathrm{M}$ & SS & $1.83 \pm 0.22$ & $3.05 \pm 0.27$ & $95.63 \pm 11.09^{*}$ & $0.46 \pm 0.04$ & $3.56 \pm 0.29$ & $0.20 \pm 0.02^{*}$ & $1.25 \pm 0.15^{*}$ \\
\hline & & SI & $2.24 \pm 0.31$ & $3.50 \pm 0.29$ & $98.31 \pm 9.27^{*}$ & $0.41 \pm 0.07$ & $3.26 \pm 0.32$ & $0.23 \pm 0.04$ & $1.49 \pm 0.16^{*}$ \\
\hline
\end{tabular}



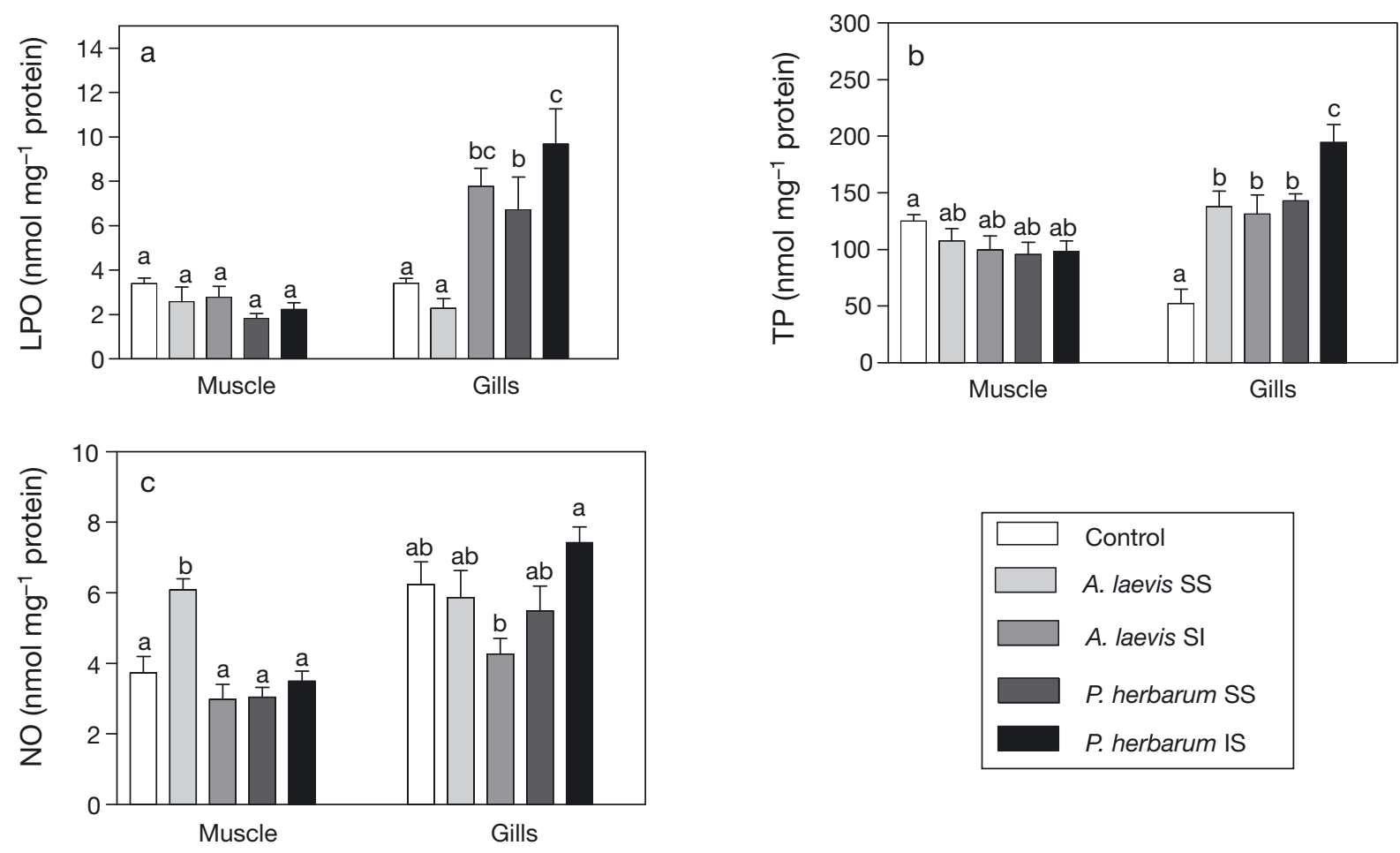

Fig. 4. Oreochromis niloticus niloticus. Effect of fungal infections with spore suspension (SS) or spore injection (SI) of Aphanomyces laevis and Phoma herbarum on oxidative stress parameters in muscles and gills of Nile tilapia: (a) lipid peroxidation (LPO), (b) total peroxide (TP) and (c) nitric oxide (NO). Different letters above bars indicate significant differences within organ $(\mathrm{p}<0.05)$

Aphanomyces to induce ulceration in fish (Dykstra et al. 1989, Dykstra \& Kane 2000, Kiryu et al. 2003, Sosa et al. 2007) but data regarding oxidant or antioxidant status in response to such fungal infections are not available in literature.

The present study showed that LPO level in gills of fish exposed to the 2 infection agents was strongly increased but was not affected in muscles of fish compared with the control. This result may be attributed due to the fact that gills are rich in blood vessels and directly exposed to water whereas white muscles of fish generally contain few mitochondria. This interpretation is in agreement with that reported by Dykstra et al. (1989) and Bone (1978). Several authors reported the prevalence of anaerobic oxidation in white muscles resulting from the limited number of mitochondria (Virani \& Rees 2000, Rees et al. 2001). The data of the present study showed that the potential destructive indicator TP gives similar results to that of LPO in both muscle and gill in response to pathogen treatment with various species and routes of administration. The significant rise of TP level in tissue may be due to activation of macrophages as well as excess production of ROS. Similarly, the occurrence of parasites in various animals (including humans) generate ROS which initiate the damaging oxidative effects (Maffei Facino et al.
1990, Maizels et al. 1993). The significant rise of both LPO and TP in gills of pathogen-infected fish may be attributed to the enhanced generation of ROS by the pathogen spores. These ROS seemed to be the first step to induce oxidative damage in some fish organs. The large elevation of NO may be indicative of oxidative stress. Little change of NO level was seen in gills and muscles of Phoma herbarum-infected fish while spores of Aphanomyces laevis increased NO level only in muscles. In mice infected by parasites, NO level showed significant increases in various organs (La Flamme et al. 2001, El-Sokkary et al. 2002). The present data of LPO, TP and NO is in accordance with that reported by Sosa et al. (2007) who found that Aphanomyces infection in striped mullet induced haemorrhagic skin, myonecrosis and mycotic granulomas. The present data agrees with that reported by Wilhelm Filho et al. (2002) who found that gill tissues are one of the main contributors of ROS generation in fish.

\section{Antioxidants}

The antioxidant levels of GSH and CAT activity (Table 3, Fig. 5a,b) showed pronounced decrease in both muscle and gills of fish exposed to infection with 

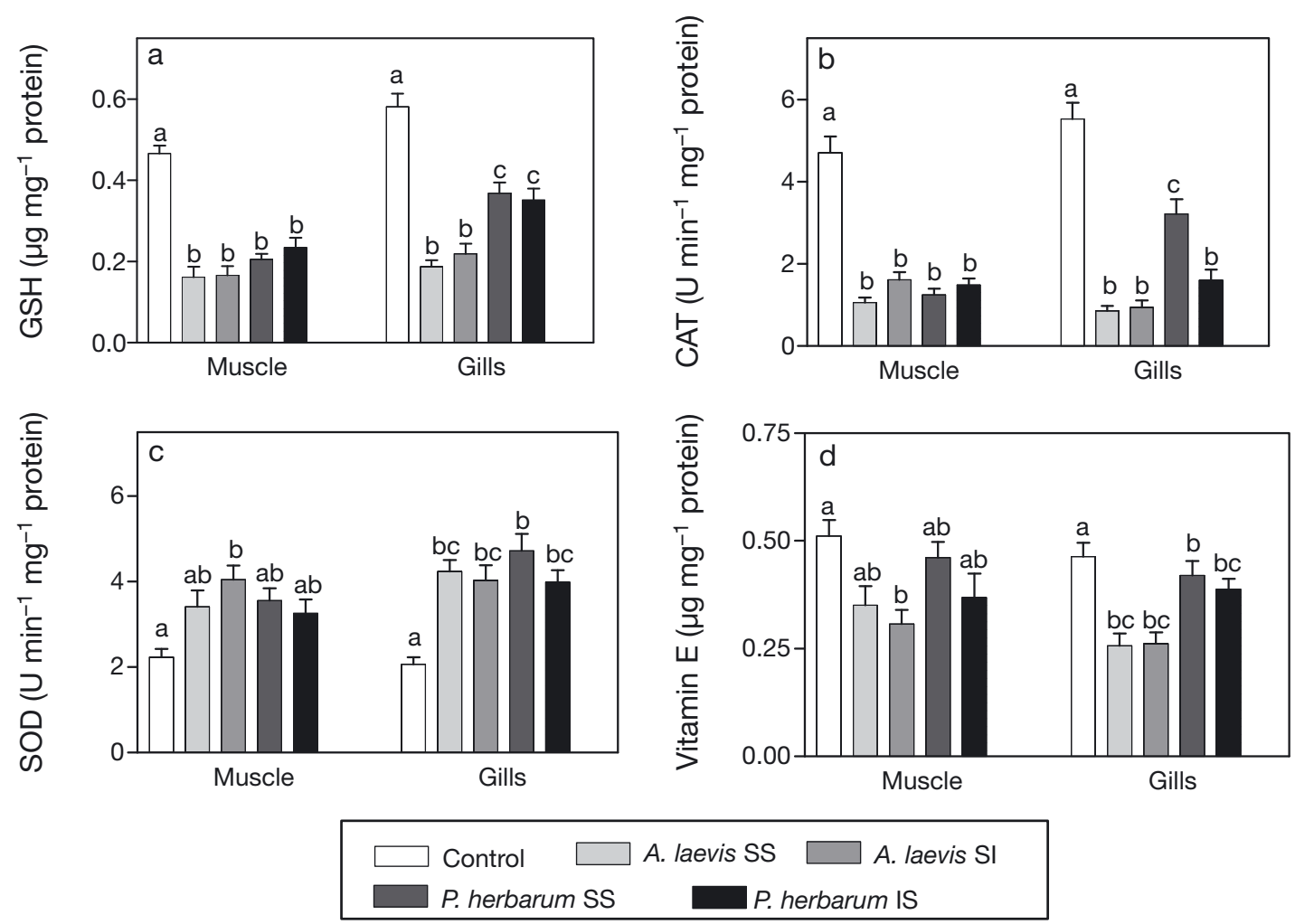

Fig. 5. Oreochromis niloticus niloticus. Effect of fungal infections with spore suspension (SS) or spore injection (SI) of Aphanomyces laevis and Phoma herbarum on antioxidants in muscles and gills of Nile tilapia: (a) glutathione (GSH), (b) catalase activity (CAT), (c) superoxide dismutase activity (SOD) and (d) vitamin E. Different letters above bars indicate significant differences within organ $(\mathrm{p}<0.05)$

the 2 tested species and routes of administration. The gill SOD activity level showed a significant rise in most fish groups treated by pathogen infections (Table 3, Fig. 5c); overproduction of ROS likely stimulates an increase of SOD activity. The powerful antioxidant vitamin E level (Table 3, Fig. 5d) was generally decreased in fish infected with Aphanomyces laevis and Phoma herbarum (both infection routes) in both muscles and gills with significant difference from controls in gills of A. laevis-infected fish.

The pronounced drop in GSH and CAT activity in the muscles and gills of fish exposed to both pathogens and both routes of administration is likely due to increased utilization of these antioxidants to counteract the overproduction of ROS after pathogen infection, as reported for parasite-infected mice (Mazen et al. 2007). When the activity of antioxidant defense systems decreases or ROS production increases, oxidative stress may occur (Packer 1996). The current data agrees with this finding; the rises of LPO and TP were mostly associated with decreased level of GSH and CAT activity especially in gills. Muscle is different from gills in that it contains fewer mitochondria and less vascularization (Bone 1978); consequently, expected ROS generation is of much lower magnitude, allowing it to be more easily normalised by antioxidants in the fish infected with the pathogen. Lushchak et al. (2005) show the activities of all antioxidant enzymes (defense system) in the white muscle of carp to be much lower than any of the other organs during hypoxia.

This idea could explain why the LPO and TP were elevated in gills but were normal in muscles treated with fungi in spite of marked drops of both CAT activity and GSH level. CAT is the main $\mathrm{H}_{2} \mathrm{O}_{2}$ detoxifying enzyme (Lópes-Torres et al. 1990, Bağnyukova et al. 2003). This drop in CAT activity may be a result of the pathogen infection that may stimulate gill and muscle tissues to produce large amounts of $\mathrm{H}_{2} \mathrm{O}_{2}$ which act as substrate to CAT enzyme to be converted into $\mathrm{H}_{2} \mathrm{O}$. In tilapia, similar results were obtained after exposure to cyanobacterial cells which decrease CAT and reductase activities in various organs including gills (Jos et al. 2005, Prieto et al. 2007). Vitamin E plays an important role in protein thiol group protection against oxidation (Naziroglu \& Butterworth 2005). The present study showed a drop in vitamin $\mathrm{E}$ in both gills and muscles in fish after pathogen infection.

In conclusion, investigation of the collected samples of the 2 freshwater fish species Oreochromis niloticus 
niloticus and Clarias gariepinus showed signs of infection, and revealed infection of the 2 most popular foodfish species in Egyptian aquaculture with diverse pathogenic species of Oomycetes and soil fungi. In addition, the pathogenicity tests of the most prevalent isolated species of Oomycetes and soil fungi on Nile tilapia fishes confirmed the susceptibility of this species to fungal infection. Oomycetes species caused higher rates of infection in the Nile tilapia than the soil fungi species as reflected in the high numbers of mortalities. The spread of infection for the Oomycetes species was more pronounced using bath exposure than cutaneous injection of inocula, whereas the reverse was true for the soil fungi. Contamination of aquaculture facilities with these fungal species will very likely result in infection of healthy fish stocks. Further studies should be initiated on these pathogenic agents of fish species to give an accurate evaluation on the biodiversity of these pathogens in Egyptian aquaculture. Our study also revealed that infection in fish with the species Aphanomyces laevis and Phoma herbarum significantly increased oxidative stress particularly in gills and induced a marked drop in most antioxidants. In addition, while both routes of pathogen administration showed nearly the same effect, A. laevis induced the highest drop in antioxidants.

Acknowledgements. The authors are gratefully indebted to Prof. Dr. A. Abdel Wahab, Prof. of Microbiology, Assiut University, Assiut, Egypt for the language corrections of this manuscript.

\section{LITERATURE CITED}

Almeida JA, Diniz YS, Marques SF, Faine LA and others (2002) The use of the oxidative stress responses as biomarkers in Nile tilapia (Oreochromis niloticus) exposed to in vivo cadmium contamination. Environ Int 27:673-679

Bağnyukova TV, Storey KB, Lushchak VI (2003) Induction of oxidative stress in Rana ridibunda during recovery from winter hibernation. J Therm Biol 28:21-28

Beers B, Sizer I (1952) A spectrophotometric method for measuring the breakdown of hydrogen peroxide by catalase. J Biol Chem 159:133-140

Bone A (1978) Locomotor muscle. In: Hoar WS, Randal DJ, Brett JR (eds) Fish physiology, Vol 7. Academic Press, New York, NY, p 301-424

Bruno DW, Poppe TT (1996) A colour atlas of salmonid diseases. Academic Press, London

Bruno DW, Wood BP (1999) Saprolegnia and other Oomycetes. In: Woo PTK, Bruno DW (eds) Fish diseases and disorders, Vol 3: viral, bacterial and fungal infections. CABI Publishing, Wallingford, p 599-659

Carballo M, Munos MJ, Cuellar M, Tarazona JV (1995) Effects of waterborne copper, cyanide, ammonia and nitrite on stress parameters and changes in susceptibility to saprolegniosis in rainbow trout (Oncorhynchus mykiss). Appl Environ Microbiol 61:2108-2112

Coker WC (1923) The Saprolegniaceae, with notes on water molds. University of North Carolina Press, Chapel Hill, NC
Crow GL, Brock JA, Kaiser S (1995) Fusarium solani fungal infection of the lateral line canal system in captive scalloped hammerhead sharks (Sphyra lewini) in Hawaii. J Wildl Dis 31:562-565

> Daugherty J, Evans TM, Skillom T, Watson LE, Money NP (1998) Evolution of spore release mechanisms in the Saprolegniaceae (Oomycetes): evidence from a phylogenetic analysis of internal transcribed spacer sequences. Fungal Genet Biol 24:354-363

Dieguez-Uribeondo J, Cerenius L, Soederhaell K (1996) Physiological characterization of Saprolegnia parasitica isolates from brown trout. Aquaculture 140:247-257

Ding AH, Nathan CF, Stuehr DJ (1988) Release of reactive nitrogen intermediates and oxygen intermediates from mouse peritoneal macrophages. Comparison of activating cytokines and evidence for independant production. J Immunol 41:2407-2412

Dykstra MJ, Kane AS (2000) Pfiesteria piscicida and ulcerative mycosis of Atlantic menhaden: current status of understanding. J Aquat Anim Health 12:18-25

> Dykstra MJ, Levine JF, Noga EJ, Hawkins JH and others (1989) Ulcerative mycosis: a serious menhaden disease of the southeastern coastal fisheries of the United States. J Fish Dis 12:175-178

> El-Sokkary GH, Omar HM, Hassanein AF, Cuzzocrea S, Reiter RJ (2002) Melatonin reduces oxidative damage and increases survival of mice infected with Schistosoma mansoni. Free Radic Biol Med 32:319-332

Ellis AE, Waddell IF, Minter DW (1983) A systemic fungal disease in Atlantic salmon parr, Salmo salar, caused by a species of Phialiophora. J Fish Dis 6:511-523

- Ellman GL (1959) Tissue sulfyhydryl groups. Arch Biochem Biophys 82:70-77

Fletcher GL, Shears MA, Goddard SV (1999) Transgenic fish for sustainable aquaculture. In: Svennig N, Reinertsen $H_{\text {, }}$ New M (eds) Sustainable aquaculture. Balkema, Rotterdam, p 193-201

> Göttlich E, van der Lubbe W, Lange B, Fiedler S and others (2002) Fungal flora in groundwater-derived public drinking water. Int J Hyg Environ Health 205:269-279

Goldstein RJ (1983) Mycotic diseases of fishes. Aquarist 7: 23-26

> Gonçalves AB, Russell R, Paterson M, Lima N (2006) Survey and significance of filamentous fungi from tap water. Int J Hyg Environ Health 209:257-264

> Gutteridge JMC (1995) Lipid peroxidation and antioxidants as biomarkers of tissue damage. Clin Chem 41:1819-1828

> Harma M, Harma M, Erel O (2005) Measurement of the total antioxidant respon in preeclampsia with a noval automated method. Eur J Obstet Gynecol Reprod Biol 118: $47-51$

Hatai K, Egusa S (1979) Studies on visceral mycosis of salmonids fry-II. Characteristics of fungi isolated from the abdominal cavity of amago salmon fry. Fish Pathol 11: 187-193

Hatai K, Fujimaki Y, Egusa S (1986) A visceral mycosis in ayu fry, Plecoglossus altivelis Temminck \& Schlegel, caused by a species of Phoma. J Fish Dis 9:111-116

> Hussein MMA, Hatai K (2002) Pathogenicity of Saprolegnia species associated with outbreaks of salmonid saprolegniosis in Japan. Fish Sci 68:1067-1072

> Jeney ZS, Jeney G (1995) Recent achievements in studies on diseases of the common carp (Cyprinus carpio L.). Aquaculture 129:397-420

Johnson RA, Zabrecky J, Kiryu Y, Shields JD (2004) Infection experiments with Aphanomyces invadans in four species of estuarine fish. J Fish Dis 27:287-295 
Johnson JW Jr (1956) The genus Achlya: morphology and taxonomy. University of Michigan, Ann Arbor, MI

Jos Á, Pichardo S, Prieto AI, Repetto G and others (2005) Toxic cyanobacterial cells containing microcystins induce oxidative stress in exposed tilapia fish (Oreochromis sp.) under laboratory conditions. Aquat Toxicol 72:261-271

Khulbe RD (1989) Infection ability of water molds in some temperate fishes of Himalaya, India. Mycoses 32:84-86

Khulbe RD, Joshi C, Bisht GS (1995) Fungal diseases of fish in Nanak Sagar, Naini Tal, India. Mycopathologia 130:71-74

Kiryu Y, Shields JD, Vogelbein WK, Kator H, Blazer VS (2003) Infectivity and pathogenicity of the oomycete Aphanomyces invadans in Atlantic menhaden Brevoortia tyrannus. Dis Aquat Org 54:135-146

Krishna L, Gupta VK, Katosh RC, Singh D (1990) Saprolegniasis in Indian major carps: an investigation. Indian Vet $\mathrm{J}$ 67:554-555

La Flamme AC, Patton EA, Bauman B, Pearce EJ (2001) IL-4 plays a crucial role in regulating oxidative damage in the liver during schistosomiasis. J Immunol 166:1903-1911

Li X, Liu Y, Song L, Liu J (2003) Responses of antioxidant systems in the hepatocytes of common carp (Cyprinus carpio L.) to the toxicity of microcystin-LR. Toxicon 42:85-89

Lightner D, Redman RM, Mohney L (1988) A renal mycosis of an adult hybrid red tilapia Oreochromis mossambicus $\times$ O. hornorum, caused by the imperfect fungus, Paecilomyces marquandii. J Fish Dis 11:437-440

Lópes-Torres M, Pérez-Campo R, Barja de Quiroga G (1990) Amino triazole effects on lung and heart $\mathrm{H}_{2} \mathrm{O}_{2}$ detoxifying enzymes and TBA-RS at two $\mathrm{PO}_{2}$. Pharmacol Toxicol 66: $27-31$

> Lowry OH, Rosebrrough NJ, Farr AL, Randall RJ (1951) Protein measurement with the Folin phenol reagent. J Biol Chem 193:265-275

Lushchak VI, Bagnyukova TV, Lushchak OV, Storey JM, Storey KB (2005) Hypoxia and recovery perturb free radical processes and antioxidant potential in common carp (Cyprinus carpio) tissues. Int J Biochem Cell Biol 37: $1319-1330$

Maffei Facino R, Carini M, Genchi C, Tofanetti O, Casciarri I, Bedoschi D (1990) Antihepatotoxic properties of uridinediphosphoglucose in liver fluke infection. Experimental fascioliasis in the rat. Arzneim-Forsch 40:490-498

Maizels RM, Bundy DAP, Selkirk ME, Smith DF, Anderson RM (1993) Immunological modulation and evasion by helminth parasites in human populations. Nature 365: 797-805

Mazen NA, Al-Salahy MB, Alrifai AA (2007) Studies on the histopathology and oxidative stress of some organs of mice infected with Toxascaris leonina (Listow, 1902) (nematoda), Egypt. Egypt J Zool 48:403-422

McGrath S, Farlow M (2005) Attack of the alien invaders. Natl Geogr Mag 207:93-117

Misra HP, Fridovich I (1972) The role of superoxide anion in the antioxidant of epinephrine and a simple assay for superoxide dismutase. J Biol Chem 247:3170-3175

> Mondal SK, De AB (2002) A fatal mycotic disease of the fresh water fish Apolcheilus panchax in India caused by Aphanomyces laevis. Mycopathologia 154:21-24

Moubasher AH (1993) Soil fungi in Qatar and other Arab countries. The Scientific and Applied Research Centre, University of Qatar, Doha

- Naziroglu M, Butterworth P (2005) Protective effect of moderate exercise with dietary vitamin $\mathrm{C}$ and $\mathrm{E}$ on blood antioxidative defense mechanism in rats with streptozotocininduced diabetes. Can J Appl Physiol 30:172-185

Ogbonna C, Alabi RO (1991) Studies on species of fungi asso- ciated with mycotic infections of fish in a Nigerian freshwater fish pond. Hydrobiologia 220:131-136

Ohkawa H, Ohishi N, Yagi N (1979) Assay for lipid peroxides in animal tissue by thiobarbituric acid reaction. Anal Biochem 95:351-358

Olufemi BE, Agius C, Roberts RJ (1983) Aspergillomycosis in intensively cultured tilapia from Kenya. Vet Rec 112: 203-204

Packer L (1996) Prevention of free radical damage in brain protection by alpha-lipoic acid. In: Packer L, Hiramatsu M, Yoshkawa $\mathrm{T}$ (eds) Free radicals in brain physiology and disorders. Academic Press, San Diego, CA, p 19-34

Pandey S, Parvez S, Sayeed I, Haque R, Bin-Hafeez B, Raisuddin S (2003) Biomarkers of oxidative stress: a comparative study of river Yamuna fish Wallago attu (Bl. \& Schn.). Sci Total Environ 309:105-115

Pitt JI (1979) The genus Penicillium and its teleomorphic states Eupenicillium and Talaromyces. Academic Press, London

Pitt JI, Hocking AD (1997) Fungi in food spoilage. Academic Press, London

Prieto AI, Pichardo S, Jos Á, Moreno I, Cameán AM (2007) Time-dependent oxidative stress response after acute exposure to toxic cyanobacterial cells containing microcystins in tilapia fish (Oreochromis niloticus) under laboratory conditions. Aquat Toxicol 84:337-345

Raper KB, Fennell DI (1965) The genus Aspergillus. Williams \& Wilkins, Baltimore, MD

Ravi K, Ramachandran B, Subramania S (2004) Effect of Eugenia jambolana seed kernel on antioxidant defense system in streptozotocin induced diabetes in rats. Life Sci 75:2717-2731

Rees BB, Sudradjat FA, Love JW (2001) Acclimation to hypoxia increases survival time of zebrafish, Danio rerio, during lethal hypoxia. J Exp Zool 289:266-272

Roe JH (1961) Standard methods of clinical chemistry, Vol 3. Academic Press, New York, NY

Sati SC (1981) Aquatic fungi of Kumaun in relation to fish infection. PhD thesis, Kumaun University, Nainital, Uttaranchal

Sayeed I, Parvez S, Pandey S, Bin-Hafeez B, Haque R, Raisuddin S (2003) Oxidative stress biomarkers of exposure to deltamethrin in freshwater fish, Channa punctatus Bloch. Ecotoxicol Environ Saf 56:295-301

Scott WW (1961) A monograph of the genus Aphanomyces. Virginia Agricult Exp Station Tech Bull (Blacksburg) 151: $1-95$

Seymour RL (1970) The genus Saprolegnia. Nova Hedwigia 19(Beih):1-124

Singhal RN, Jeet S, Davies RW (1987) Experimental transmission of Saprolegnia and Achlya to fish. Aquaculture 64: 1-7

Smith D, Onions HS (1983) The preservation and maintenance of living fungi. Commonwealth Mycological Institute, Richmond

Sosa ER, Landsberg JH, Stephenson CM, Forstchen AB, Vandersea MW, Litaker RW (2007) Aphanomyces invadans and ulcerative mycosis in estuarine and freshwater fish in Florida. J Aquat Anim Health 19:14-26

Sparrow FK (1960) Aquatic phycomycetes, 2nd edn. University of Michigan Press, Ann Arbor, MI

Stueland S, Hatai K, Skaar I (2005) Morphological and physiological characteristics of Saprolegnia spp. strains pathogenic to Atlantic salmon, Salmo salar L. J Fish Dis 28: $445-453$

Van West P (2006) Saprolegnia parasitica, an oomycete pathogen with a fishy appetite: new challenges for an old problem. Mycologist 20:99-104 
Virani NA, Rees BB (2000) Oxygen consumption, blood lactate and inter-individual variation in the gulf killifish, Fundulus grandis, during hypoxia and recovery. Comp Biochem Physiol 126:397-405

Wang H, Wei W, Zhang SY, Shen YX, Yue L, Wang NP, Xu SY (2005) Melatonin-selenium nanoparticles inhibit oxidative stress and protect against hepatic injury induced by Bacillus Calmette-Guérin/lipopolysaccharide in mice. J Pineal Res 39:156-163

Wilhelm Filho D, Sell F, Ribeiro L, Ghislandi M and others

Editorial responsibility: David Bruno,

Aberdeen, UK
(2002) Comparison between the antioxidant status of terrestrial and diving mammals. Comp Biochem Physiol A Mol Integr Physiol 133:885-892

> Willoughby LG, Pickering AD (1977) Viable Saprolegniaceae spores on the epidermis of the salmonid fish Salmo trutta and Salvelinus alpinus. Trans Br Mycol Soc 68:91-95

Wolf JC, Smith SA (1999) Systemic zygomycosis in farmed tilapia fish. J Comp Pathol 121:301-306

Yanong RP (2003) Fungal diseases of fish. Vet Clin North Am Exot Anim Pract 6:377-400

Submitted: January 7, 2010; Accepted: September 22, 2010

Proofs received from author(s): March 1, 2011 